The Holocene

\title{
Sub sea surface temperatures in the Polar North Atlantic during the Holocene: Planktic foraminiferal $\mathrm{Mg} / \mathrm{Ca}$ temperature reconstructions
}

\begin{tabular}{|c|c|}
\hline Journal: & The Holocene \\
\hline Manuscript ID: & HOL-13-0053.R1 \\
\hline Manuscript Type: & Paper \\
\hline Date Submitted by the Author: & $\mathrm{n} / \mathrm{a}$ \\
\hline Complete List of Authors: & $\begin{array}{l}\text { Aagaard-Sørensen, Steffen; University of Troms } \varnothing \text {, Department of Geology } \\
\text { Husum, Katrine; University of Troms } \varnothing \text {, Department of Geology } \\
\text { Hald, Morten; University of Troms } \varnothing \text {, Department of Geology } \\
\text { Marchitto, Thomas; University of Colorado, Department of Geological } \\
\text { Sciences and Institute of Arctic and Alpine Research } \\
\text { Godtliebsen, Fred; University of Troms } \varnothing, \text { Department of Mathematics and } \\
\text { Statistics }\end{array}$ \\
\hline Keywords: & $\begin{array}{l}\text { Paleoceanography, Polar North Atlantic, Fram Strait, Atlantic water, Trace } \\
\text { elements, sub SST reconstruction }\end{array}$ \\
\hline Abstract: & 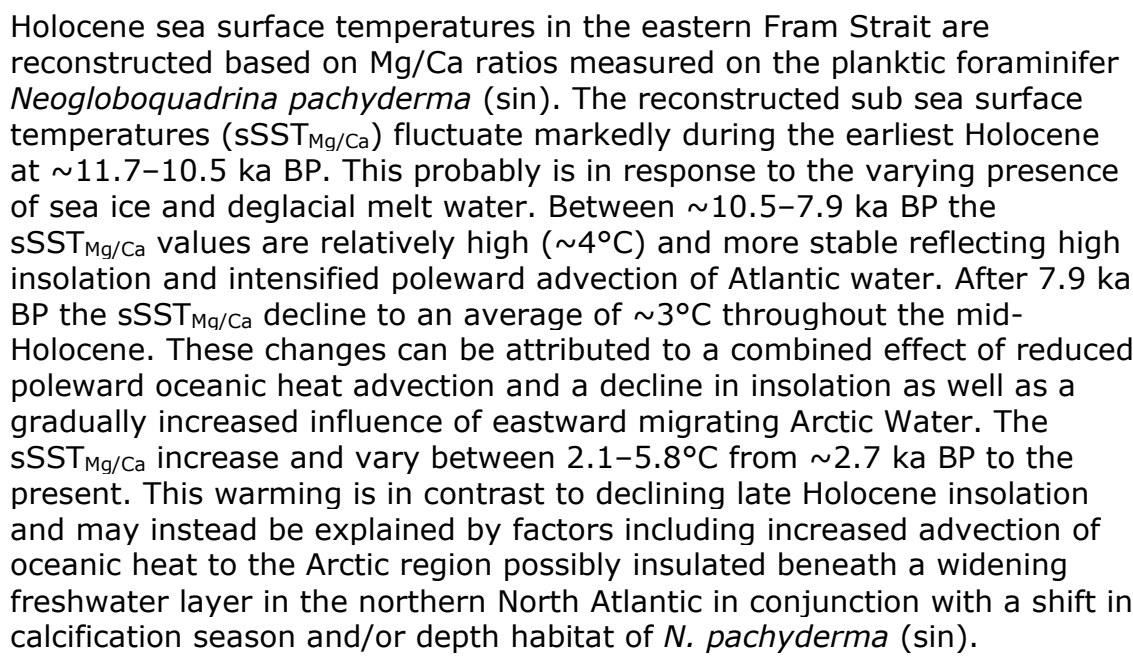 \\
\hline
\end{tabular}

\section{SCHOLARONE ${ }^{m}$ \\ Manuscripts}


1 Sub sea surface temperatures in the Polar North Atlantic during the Holocene:

Planktic foraminiferal $\mathrm{Mg} / \mathrm{Ca}$ temperature reconstructions

3

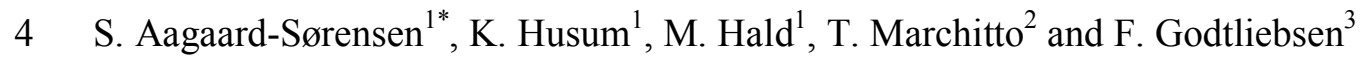

5

$6 \quad{ }^{1}$ Department of Geology, University of Tromsø, 9037 Tromsø, Norway

7

$8 \quad{ }^{2}$ Department of Geological Sciences and Institute of Arctic and Alpine Research, University

9 of Colorado, Campus Box 450, Boulder, Colorado 80309, USA

10

$11{ }^{3}$ Department of Mathematics and Statistics, University of Tromsø, 9037 Tromsø, Norway

15 *Author for correspondence: (e-mail: Steffen.Sorensen@uit.no)

16

17 Key words: Paleoceanography, Polar North Atlantic, Fram Strait, Atlantic water, Trace

18 elements, sub SST reconstruction

19

20

21

22

23

24

25 


\section{Abstract}

27 Holocene sea surface temperatures in the eastern Fram Strait are reconstructed based on

$28 \mathrm{Mg} / \mathrm{Ca}$ ratios measured on the planktic foraminifer Neogloboquadrina pachyderma (sin). The

29 reconstructed sub sea surface temperatures $\left(\mathrm{SSST}_{\mathrm{Mg} / \mathrm{Ca}}\right)$ fluctuate markedly during the earliest

30 Holocene at $\sim 11.7-10.5 \mathrm{ka} \mathrm{BP}$. This probably is in response to the varying presence of sea

31 ice and deglacial melt water. Between $\sim 10.5-7.9 \mathrm{ka} \mathrm{BP}$ the $\mathrm{SSST}_{\mathrm{Mg} / \mathrm{Ca}}$ values are relatively

32 high $\left(\sim 4^{\circ} \mathrm{C}\right)$ and more stable reflecting high insolation and intensified poleward advection of

33 Atlantic water. After $7.9 \mathrm{ka} \mathrm{BP}$ the $\mathrm{sSST}_{\mathrm{Mg} / \mathrm{Ca}}$ decline to an average of $\sim 3^{\circ} \mathrm{C}$ throughout the

34 mid-Holocene. These changes can be attributed to a combined effect of reduced poleward

35 oceanic heat advection and a decline in insolation as well as a gradually increased influence

36 of eastward migrating Arctic Water. The $\mathrm{sSST}_{\mathrm{Mg} / \mathrm{Ca}}$ increase and vary between $2.1-5.8^{\circ} \mathrm{C}$

37 from $\sim 2.7 \mathrm{ka} \mathrm{BP}$ to the present. This warming is in contrast to declining late Holocene

38 insolation and may instead be explained by factors including increased advection of oceanic

39 heat to the Arctic region possibly insulated beneath a widening freshwater layer in the

40 northern North Atlantic in conjunction with a shift in calcification season and/or depth habitat

41 of $N$. pachyderma $(\sin )$.

\section{Introduction}

43 In order to elucidate climate changes observed in Arctic environments today, it is necessary

44 to improve the knowledge of long term natural climatic and oceanographic variations in the

45 region (IPCC, 2007). At present, northward advection of Atlantic Water into the Nordic Seas

46 and on to the Arctic is the main oceanic source of heat and salt for the Arctic Ocean (Schauer

47 et al., 2004). During the Holocene other forcing mechanisms such as long-term orbital

48 changes associated with insolation variability (Berger and Loutre, 1991), changes in

49 atmospheric pressure systems resulting in displacement of primary wind patterns (North

50 Atlantic Oscillation index) and alteration of Atlantic Water flux into the Nordic Seas (Hurrell, 
51 1995; Nesje et al., 2001) have been suggested to have a large impact on climatic and

52 oceanographic development in the Nordic Seas and the Arctic. Paleoceanographic variability,

53 including temporal and spatial variation of Atlantic Water flux, temperature and salinity has

54 previously been studied using a range of different proxies based on planktic foraminifera in

55 the Nordic Seas during the Holocene. These include stable oxygen and carbon isotopes in

56 foraminiferal tests (e.g. Bauch et al., 2001; Rasmussen et al., 2007) and distribution patterns

57 of planktic foraminifera and transfer functions (e.g. Hald et al., 2007). Reconstructions of

58 SST using transfer functions in the Arctic may be hampered by the databases representing

59 modern conditions. The databases have a limited geographical coverage in the Arctic

60 meaning that not all environmental gradients of the region are represented (e.g. Husum and

61 Hald, 2012; Kucera et al., 2005). Moreover, stable oxygen isotopes recorded within

62 foraminiferal calcite inherently reflect both the temperature and the $\delta^{18} \mathrm{O}$ signal of ambient

63 seawater (e.g. Shackleton, 1974). Therefore, additional proxies for paleo-SST are needed to

64 elucidate cold-end temperature variability. Recent studies have utilized $\mathrm{Mg} / \mathrm{Ca}$ ratios in

65 planktic foraminifera to reconstruct sub sea surface temperatures $\left(\mathrm{sSST}_{\mathrm{Mg} / \mathrm{Ca}}\right)$ in the Fram

66 Strait during the Late Glacial/Holocene transition and the late Holocene (Aagaard-Sørensen

67 et al., submitted; Spielhagen et al., 2011). Here, we present the first record of $\mathrm{SSST}_{\mathrm{Mg} / \mathrm{Ca}}$ from

68 the entire Holocene in the high Arctic based on trace elements. A sediment core located under

69 the present day inflow of Atlantic Water, carried within the West Spitsbergen Current

70 (WSC), has been investigated (Figure 1A). Trace element analyses have been conducted on

71 the planktic foraminifer Neogloboquadrina pachyderma ( $\sin ) . \mathrm{Mg} / \mathrm{Ca}$ ratios were used to

72 reconstruct sub surface water temperatures $\left(\mathrm{sSST}_{\mathrm{Mg} / \mathrm{Ca}}\right)$ representing the primary habitat depth

73 and season of calcification for N. pachyderma $(\sin )$.

74 In addition, $\% \mathrm{CaCO}_{3}$ and $\% \mathrm{TOC}$ variations in the sediment were used to assess potential

75 preservation changes of foraminiferal calcite in the record. 


\section{Oceanographic setting}

77 Atlantic Water is advected northward in the North Atlantic Current (NAC; $>2{ }^{\circ} \mathrm{C}, \mathrm{S}>35$ )

78 (Hopkins, 1991) and is transported into the Nordic Seas across the Iceland-Faroes-Scotland 79 ridge systems at $\sim 62^{\circ} \mathrm{N}$ (Hansen and Østerhus, 2000) (Figure $1 \mathrm{~A}$ ). At ca. $70^{\circ} \mathrm{N}$ the water

80 mass bifurcates with one branch entering the SW Barents Sea while the other branch

81 continues north along the west Barents Sea and Spitsbergen slopes as the West Spitsbergen

82 Current (WSC) (Schauer et al., 2004) (Figure 1A). Atlantic Water (T: 3 to $7^{\circ} \mathrm{C}$; S: 34.9 to

83 35.2) is carried by the WSC into the Arctic Ocean in the eastern part of the Fram Strait where

84 it occupies the upper $\sim 700$ meters of the water column (Schauer et al., 2004; Walczowski et

85 al., 2005) (Figure 1A). In the Fram Strait the Atlantic Water submerges at $\sim 78^{\circ} \mathrm{N}$ and partly

86 turns back to the south (Bourke et al., 1988) underneath the southward flowing East

87 Greenland Current (Rudels et al. 2005) (Figure 1A). The remaining Atlantic Water disperses

88 into several sub currents in the Arctic Ocean (Manley, 1995).

89 In the eastern Fram Strait modern temperatures of the surface mixed layer (0 to $25 \mathrm{~m}$

90 water depth) reach $8.2^{\circ} \mathrm{C}$ and a salinity up to 34.95 (August 2006) (Figure 1B). Below, from

9125 to $550 \mathrm{~m}$ water depth Atlantic Water $\left(\mathrm{T} \sim 4^{\circ} \mathrm{C} ; \mathrm{S}=35\right.$ to 35.15$)$ occupies the water column

92 and overlays Atlantic Intermediate Water $\left(\mathrm{T}>0{ }^{\circ} \mathrm{C} ; \mathrm{S} \sim 34.9\right)$. Deep Water is found from $900 \mathrm{~m}$

93 water depth $\left(\mathrm{T}<0^{\circ} \mathrm{C}, \mathrm{S} \sim 34.9\right)$.

94 Material and methods

95 Kastenlot core MSM05/5-712-2 (7854.94’N, 06 46.03’E; 1488 m water depth; $894 \mathrm{~cm}$

96 length) was collected during a cruise with RV "Maria S. Merian” in August 2007 at the West

97 Spitsbergen slope, eastern Fram Strait (Figure 1A).

$98 \quad$ Age model

99 The age model of MSM05/5-712-2 was constructed on the basis of $10 \mathrm{AMS}{ }^{14} \mathrm{C}$ dates and

100 mean of the $2 \sigma$ age ranges were used as tie points in the linear interpolation (Table 1, Figure 
101 2). The $\mathrm{AMS}{ }^{14} \mathrm{C}$ dates were carried out on planktic foraminiferal tests (N. pachyderma (sin))

102 from the upper $441 \mathrm{~cm}$ of the sediment core (Giraudeau (in prep); Werner et al., 2013).

103 Radiocarbon dates were calibrated with Calib version 6.0 (Reimer et al., 2005; Stuiver et al.,

104 2005) using the marine calibration curve Marine09 (Hughen et al., 2004; Reimer et al., 2009).

105 The standard marine reservoir correction of 400 years $(\mathrm{R})$ was used in all calibrations. The

106 local reservoir age $(\Delta \mathrm{R}=151 \pm 51)$ from Magdalenefjorden, Svalbard was used in the

107 calibration (Mangerud et al., 2006; Mangerud and Gulliksen, 1975) (Table 1). All calibrated

108 ages are an expression of years before present (1950). The Younger Dryas/Holocene

109 boundary (11.75 ka BP) used on figures follows Walker et al. (2009).

$110 \quad$ Trace element analysis and contaminants

111 The sediment core was sub sampled in $1 \mathrm{~cm}$ thick slices, and then freeze dried and wet sieved

112 trough $1 \mathrm{~mm}, 100 \mu \mathrm{m}$ and $63 \mu \mathrm{m}$ mesh sizes. Trace element analysis was performed on the

113 planktic foraminifer Neogloboquadrina pachyderma (sinistral coiling) (ca. 50 tests/sample)

114 and the trace element ratios $\mathrm{Mg} / \mathrm{Ca}, \mathrm{Mn} / \mathrm{Ca}, \mathrm{Fe} / \mathrm{Ca}$, and $\mathrm{Al} / \mathrm{Ca}$ were measured (Figure 3 and

115 4). Tests were picked at $2 \mathrm{~cm}$ and $3 \mathrm{~cm}$ resolution in the upper part (0 to $210 \mathrm{~cm})$ and lower

116 part (210 to $441 \mathrm{~cm}$ ) of the sediment core, respectively, resulting in a temporal resolution of

$117 \sim 36$ to $120 \mathrm{yr} /$ sample. Given that partial dissolution and contamination of tests can bias the

118 trace element analysis, dirty and sediment filled tests or tests visibly influenced by dissolution

119 (i.e. broken tests or tests with missing chambers) were avoided. Furthermore, tests were

120 picked within a relatively narrow size range, with minimum and maximum length of the tests

121 ranging from ca. 225 to $290 \mu \mathrm{m}$, to reduce size dependent bias on the $\mathrm{Mg} / \mathrm{Ca}$ measurements

122 (Elderfield et al., 2002). Prior to analysis the foraminiferal tests were crushed and reductively

123 (anhydrous hydrazine) and oxidatively $\left(\mathrm{H}_{2} \mathrm{O}_{2}\right)$ cleaned (Boyle and Keigwin, 1985; Boyle and

124 Rosenthal, 1996). Subsequently the samples were analyzed by magnetic-sector single

125 collector ICP-MS, on a Thermo-Finnigan Element2 at the Litmann laboratory, University of 
126 Colorado operating with a long-term $1 \sigma$ precisions of $0.54 \%$ for $\mathrm{Mg} / \mathrm{Ca}$ measurements

127 (Marchitto, 2006). Replicate analysis was carried out for approximately every 30 samples.

128 The average reproducibility of sample splits was $\pm 0.039 \mathrm{mmol} / \mathrm{mol}(\mathrm{n}=4)$ in regards to

$129 \mathrm{Mg} / \mathrm{Ca}$ which on average is below $<5 \%$ difference between duplicate measurements (Figure

$1304 \mathrm{C}$ ). $\mathrm{Fe}, \mathrm{Al}$ and $\mathrm{Mn}$ are tracers of contaminating phases that might bias the $\mathrm{Mg} / \mathrm{Ca}$ ratios

131 measured in foraminiferal calcite (Barker et al., 2003). Fe and Al are tracers of detrital

132 material contamination (silicate minerals) and $\mathrm{Mn}$ is tracer of secondary diagenetic Mn-rich

133 carbonate coating (Boyle, 1983). Weak correlation between $\mathrm{Mg}$ and $\mathrm{Fe}\left(\mathrm{R}^{2} \sim 0.26\right)$ and $\mathrm{Mn}$

$134\left(\mathrm{R}^{2} \sim 0.21\right)$ is observed whereas Al shows no significant correlation to $\mathrm{Mg}\left(\mathrm{R}^{2} \sim 0.03\right)$ (Figure

$1353 \mathrm{~A}, \mathrm{~B}, \mathrm{C}$ ). Samples with $>100 \mu \mathrm{mol} / \mathrm{mol}$ of $\mathrm{Fe}, \mathrm{Al}$ and $\mathrm{Mn}$ (Barker et al., 2003) in addition to

136 samples with $<5 \mu \mathrm{g} \mathrm{CaCO}_{3}$ recovery (Marchitto, 2006) were omitted (Figure 4C).

137 Water temperature reconstructions

138 Temperature of the ambient sea water is considered to be the primary controlling factor on

$139 \mathrm{Mg} / \mathrm{Ca}$ ratios recorded in foraminiferal calcite (Elderfield and Ganssen, 2000; Lea et al.,

140 1999; Nürnberg et al., 1996). The thermodynamic control on the Mg uptake into

141 foraminiferal calcite shows positive exponential relation between temperature and $\mathrm{Mg}$ uptake

142 which approximates a linear relationship at narrow temperature ranges (Elderfield and

143 Ganssen, 2000; Kozdon et al., 2009; Kristjánsdóttir et al., 2007).

144 Sub sea surface temperatures $\left(\mathrm{sSST}_{\mathrm{Mg} / \mathrm{Ca}}\right)$ were calculated using $\mathrm{Mg} / \mathrm{Ca}$ ratios and the species

145 specific (N. pachyderma (sin)) linear equation of Kozdon et al. (2009) (Figure 4, 5, 6):

$146 \mathrm{Mg} / \mathrm{Ca}\left(\mathrm{mmol} \mathrm{mol}^{-1}\right)=0.13( \pm 0.037) * \mathrm{~T}+0.35( \pm 0.17)($ Eq. 1)

147 This equation is based on cross calibrated $\mathrm{Mg} / \mathrm{Ca}$ and $\delta^{44 / 40} \mathrm{Ca}$ proxy signals of $N$.

148 pachyderma $(\mathrm{sin})$ from Nordic Sea core top samples and produces reliable $\mathrm{SSST}_{\mathrm{Mg} / \mathrm{Ca}}$

149 estimates at temperatures above $\sim 3^{\circ} \mathrm{C}$ (Kozdon et al., 2009). It must be cautioned that the 


\section{HOLOCENE}

150 equation is based on samples that have not undergone the reductive cleaning step (Kozdon et

151 al., 2009).

$152 \quad$ SiZer analysis

153 SiZer (Significance of Zero Crossings of the Derivative) analysis described by Chaudhuri and

154 Marron (1999) was performed on the $\mathrm{SSST}_{\mathrm{Mg} / \mathrm{Ca}}$ data to reveal significant features in the

155 proxy record (Figure 6C). The analysis has previously been applied to Arctic paleo proxy

156 records to reveal significant features at particular levels of resolution and eliminating

157 insignificant natural variability (e.g. Hald et al., 2004; Wilson et al., 2011). The method

158 assumes that individual values are independent random variables. The analyses smooth the

159 data from minimum to maximum resolution and generate a SiZer map which examines the

160 data across a range of resolutions (bandwidth, h) and uses color codes to classify the

161 derivatives of the smoothed data as significantly decreasing, increasing or exhibiting no

162 significant change (Figure 6C).

\section{Results}

164 The record of $\mathrm{Mg} / \mathrm{Ca}$ ratios measured on $\mathrm{N}$. pachyderma (sin) has an average value of 0.809

$165 \mathrm{mmol} / \mathrm{mol}(\mathrm{n}=152 ; 1 \sigma=0.11)$ corresponding to an average temperature of $3.5^{\circ} \mathrm{C}$ (Figure

$1664 \mathrm{C}, \mathrm{D})$. Measurements of $\mathrm{Mg} / \mathrm{Ca}$ ratios showing possible sample contamination have been

167 removed from the record (Figure 4C, D).

168 During the earliest Holocene the $\mathrm{SSST}_{\mathrm{Mg} / \mathrm{Ca}}$ values are relatively high and fluctuating between

1691.9 and $5.2^{\circ} \mathrm{C}$ (Figure 4D). Between $\sim 10.5-7.9 \mathrm{ka} \mathrm{BP}$ the $\mathrm{sSST}_{\mathrm{Mg} / \mathrm{Ca}}$ are relatively high

170 values with an average of $\sim 4^{\circ} \mathrm{C}$ (Figure 4D). After $\sim 7.9 \mathrm{ka} \mathrm{BP}$ the $\mathrm{sSST}_{\mathrm{Mg} / \mathrm{Ca}}$ decline rapidly

171 to $<3{ }^{\circ} \mathrm{C}$. The mid Holocene is characterized by two cold periods, $\sim 7.9-6 \mathrm{ka}$ BP and 5.2-2.7

$172 \mathrm{ka} \mathrm{BP}$, with an average $\mathrm{sSST}_{\mathrm{Mg} / \mathrm{Ca}}$ of $\sim 3^{\circ} \mathrm{C}$ bracket an interval with slightly elevated

$173 \mathrm{sSST}_{\mathrm{Mg} / \mathrm{Ca}}\left(\sim 3.5^{\circ} \mathrm{C}\right)$. During the Late Holocene the $\mathrm{sSST}_{\mathrm{Mg} / \mathrm{Ca}}$ values gradually increase 
174 towards the present. The highest values averaging $\sim 5^{\circ} \mathrm{C}$ are recorded after $\sim 1 \mathrm{ka} \mathrm{BP}$ (Figure

175 4D).

176 The SiZer analysis identifies a multi-millennial $\mathrm{sSST}_{\mathrm{Mg} / \mathrm{Ca}}$ decline from $\sim 11.7-6 \mathrm{ka} \mathrm{BP}$ with

177 a significant sub-millennial decrease around 7.9 ka BP (Figure 6C). From $\sim 6-3$ ka BP no

178 significant change is observed. A significant warming on multi decadal to multi millennial

179 time scale is initiates at $\sim 3 \mathrm{ka} \mathrm{BP}$ (Figure 6C).

\section{Discussion}

181 Assessment of reconstructed $S S S T_{M g / C a}$ and calcium carbonate preservation state

182 During analysis the foraminiferal calcite undergoes reductive and oxidative cleaning (see

183 material and methods for details). The reductive cleaning decreases the $\mathrm{Mg} / \mathrm{Ca}$ ratio by up to

$184 \quad 10-15 \%$ potentially lowering the reconstructed $\mathrm{sSST}_{\mathrm{Mg} / \mathrm{Ca}}$ (Barker et al., 2003).

185 Comparison of reconstructed $\mathrm{sSST}_{\mathrm{Mg} / \mathrm{Ca}}$ with summer $\mathrm{SSST}_{\text {SIMMAX }}$ based on foraminiferal

186 distribution patterns in the same core (Werner et al., 2013) shows similar temperature ranges

187 of 1.9 to $5.8^{\circ} \mathrm{C}$ and 0.9 to $6.1^{\circ} \mathrm{C}$, respectively (Figure 5C). It should be noted that below the

188 lower limit of sensitivity for Eq. $1\left(<3^{\circ} \mathrm{C}\right)$ (Kozdon et al., 2009) the $\mathrm{Mg} / \mathrm{Ca}$ method does not

189 reproduce comparable low temperature estimates as the $\operatorname{sSST}_{\text {SIMMAX }}$ (Werner et al., 2013)

190 (Figure 5C). In order to estimate the potential impact of $\mathrm{Mg}$ loss during reductive cleaning

191 (Barker et al., 2003) we artificially increased the $\mathrm{Mg} / \mathrm{Ca}$ ratio by $15 \%$ in figure $5 \mathrm{C}$. The

192 resulting $\mathrm{SSST}_{\mathrm{Mg} / \mathrm{Ca}+15 \%}$ calculated using Eq. 1 (Kozdon et al., 2009) shows increases of 0.7 to

$1931.3^{\circ} \mathrm{C}$ generally producing higher estimates than $\mathrm{SSST}_{\text {SIMMAX }}$ (Figure 5C). Therefore the

194 potential Mg loss during the reductive cleaning (i.e. lower reconstructed temperature) in our

195 record is considered of minor importance.

196 Further, $\mathrm{Mg} / \mathrm{Ca}$ ratios were measured in core-top N. pachyderma $(\sin )$ (Core MSM5/5-712-1)

197 obtained from same core location as MSM5/5-712-2 (Speilhagen et al., 2011) (Figure 1). The

198 material underwent the same cleaning procedure as applied in the present study (Spielhagen 
199 et al., 2011). The core-top $\mathrm{sSST}_{\mathrm{Mg} / \mathrm{Ca}}$ is $\sim 5.1^{\circ} \mathrm{C}$ when calculated using the temperature

200 equation of Elderfield \& Ganssen (2000) (Speilhagen et al., 2011) (Figure 5B) and $\sim 3.7^{\circ} \mathrm{C}$

201 when recalculated using Eq.1 (Figure 5B) (Kozdon et al., 2009). Both values are within or

202 close to the modern temperature range (August 2009) observed at the main N. pachyderma

203 (sin) habitat depth of 50-200 m water depth (Figure 1B, 5C). These findings further show that

204 any potential $\mathrm{Mg}$ loss during cleaning procedures is of minor importance for the

205 reconstructed temperatures.

206 Studies have shown that dissolution of calcium carbonate is a prominent feature in paleo-

207 records from the Fram Strait especially after $\sim 8$ ka BP (Bauch et al., 2001; Rasmussen et al.,

208 2007; Zamelczyk et al., 2012). Post mortem dissolution of foraminiferal calcite may

209 preferentially remove $\mathrm{Mg}$ rich parts from foraminiferal tests and consequently bias $\mathrm{Mg} / \mathrm{Ca}$

210 ratio based temperature reconstructions towards lower, colder values (Brown and Elderfield,

211 1996; Johnstone et al., 2011; Rosenthal et al., 2000). In order to minimize the risk of

212 measuring on material influenced by dissolution only the most pristine test were picked for

213 trace element analysis (see material and methods section for more details). Further, $\% \mathrm{CaCO}_{3}$

214 and \% TOC variations in the sediment can be used to tentatively assess potential preservation

215 changes of foraminiferal calcite in the record (Figure 4A, B). The sediment holds low content

216 of $\mathrm{CaCO}_{3}(\leq 5 \mathrm{wt} . \%)$ and high content of total organic carbon (\%TOC) prior to $\sim 10 \mathrm{ka} \mathrm{BP}$

217 (Aagaard et al., submitted) (Figure 4A, B) which may suggest potential post-depositional

218 dissolution due to respiratory release of $\mathrm{CO}_{2}$ and decrease of pore water $\mathrm{pH}$ during organic

219 material degradation within the sediment (e.g. Archer et al., 1989; Emerson and Bender,

220 1981; Huber et al., 2000). After $\sim 10 \mathrm{ka}$ BP to the present high $\% \mathrm{CaCO}_{3}$ and low $\% \mathrm{TOC}$

221 generally indicates good preservation potential, apart from the mid-Holocene ( $\sim 6-3 \mathrm{ka} \mathrm{BP})$

222 where relatively low $\% \mathrm{CaCO}_{3}$ and moderate $\% \mathrm{TOC}$ content has been recorded (Müller at al.,

223 2012). This could indicate preservation problems although to a lesser extent than during the 
224 earliest Holocene (4 A,B). To what extent preservation/dissolution has influenced the $\mathrm{Mg} / \mathrm{Ca}$

225 ratios recorded by N. pachyderma $(\sin )$ is not possible to quantify from the present set of

226 proxies. However, it cannot be excluded that the preservation changes of foraminiferal tests

227 during the Holocene may have influenced the reconstructed $\mathrm{SSST}_{\mathrm{Mg} / \mathrm{Ca}}$ values.

228

229 Holocene sSST variability

230 Based on the $\mathrm{sSST}_{\mathrm{Mg} / \mathrm{Ca}}$ record and significant changes identified by the SiZer analysis the

231 paleorecord of core MSM5/5-712-2 can be divided into three intervals: The relatively warm

232 early (11.7-7.9 ka BP), cold mid (7.9-2.7 ka BP) and warm late (2.7-0.3 ka BP) Holocene

233 (Figure 4, 6).

234 Early Holocene (11.7-7.9 ka BP)

235 Previous studies from the Fram Strait have shown that the early Holocene was characterized

236 by a strong influence of sea ice, icebergs and glacial melt water prior to $\sim 10.5 \mathrm{ka} \mathrm{BP}$

237 (Aagaard-Sørensen et al., submitted; Ebbesen et al., 2007; Rasmussen et al., 2007;

238 Ślubowska-Woldengen et al., 2005). The low $\mathrm{SSST}_{\mathrm{Mg} / \mathrm{Ca}}$ recorded at $\sim 11-11.3 \mathrm{ka} \mathrm{BP}$

239 (represented by 3 data points) (Figure 6D) possibly reflects a cooling associated with the brief

240 but distinct climatic event, the Preboreal Oscillation (PBO). The PBO has been documented

241 in both marine and terrestrial records in and around the Nordic Seas (e.g. Björck et al., 1997;

242 Hald and Hagen, 1998; Husum and Hald, 2002; Rasmussen, SO et al., 2007). The PBO has

243 been attributed to increased deglacial melt water fluxes into the Nordic and Arctic Seas

244 resulting in hampered heat transport via the North Atlantic conveyor and enhanced sea ice

245 export into the Fram Strait (Fisher et al., 2002; Hald and Hagen 1998).

246 In the present record the highest early Holocene $\operatorname{sSST}_{\mathrm{Mg} / \mathrm{Ca}}$ (average $\sim 4^{\circ} \mathrm{C}$ ) is found between

$247 \sim 10.5$ to 7.9 ka BP (Figure 6D). A marked summer $\mathrm{sSST}_{\mathrm{Mg} / \mathrm{Ca}}$ increase initiated at $\sim 11 \mathrm{ka} \mathrm{BP}$

248 and subsequent peak values between $\sim 10.5-8.7 \mathrm{ka}$ BP has been recorded along the Barents 
249 Sea and West Spitsbergen slopes via planktic foraminiferal transfer functions ( $\mathrm{sSST}_{\text {Transfer }}$ )

250 (Ebbesen et al., 2007; Hald et al., 2007; Husum and Hald, 2012; Sarnthein et al., 2003)

251 (Figure 6F, G). The summer sSST increase along the West Spitsbergen slope is part of a

252 south to north time-transgressive development in the Nordic Seas, where the remnant cold

253 water and sea ice gradually was displaced by Atlantic Water (Hald et al., 2007).

254 Risebrobakken et al. (2011) argue that strong melt water discharge resulted in weak

255 ventilation of the Nordic Seas until $11 \mathrm{ka} \mathrm{BP.} \mathrm{A} \mathrm{buildup} \mathrm{of} \mathrm{an} \mathrm{Atlantic} \mathrm{subsurface} \mathrm{reservoir}$

256 of heat and salt eventually resulted in rejuvenation of strong and deep overturning circulation

257 and intensified early Holocene northward heat advection into the Nordic Seas peaking at 10

258 ka BP (Risebrobakken et al., 2011). Predominantly positive North Atlantic Oscillation (NAO)

259 index values reconstructed by Nesje et al. (2001) also support stronger northward advection

260 of Atlantic Water during the early Holocene (Hurrell, 1995). The NAO index is defined as

261 the atmospheric pressure difference between Iceland and the Azores with positive index

262 values indicating a larger pressure difference, resulting in stronger westerlies which increase

263 wind driven Atlantic Water influx to the Nordic Seas (Hurrell, 1995).

264 Within the significant multi-millennial $\mathrm{sSST}_{\mathrm{Mg} / \mathrm{Ca}}$ decline observed throughout the early part

265 of the record a faster multi-centennial decline is observed following the relatively high early

266 Holocene $\mathrm{sSST}_{\mathrm{Mg} / \mathrm{Ca}}$ from $\sim 10.5$ to $7.9 \mathrm{ka} \mathrm{BP}$ (Figure 6C, D). An early to middle Holocene

267 cooling has been recorded in different proxy records in the Nordic Sea including distribution

268 patterns of diatoms (Birks and Koç, 2002; Koç et al., 1993) and benthic and planktic

269 foraminifera (Hald and Aspeli, 1997; Hald et al., 2004; Ebbesen et al., 2007; Knudsen et al.,

270 2004; Rasmussen et al., 2007; Werner et al., 2013). The observed pattern could be a

271 reflection of the high and declining summer insolation (Berger and Loutre, 1991) (Figure

272 6A). However, studies suggest that insolation changes primarily influence the uppermost part

273 (summer mixed layer down to $\sim 20-40 \mathrm{~m}$ water depth) of the water column (e.g. Andersson et 


\section{HOLOCENE}

274

275

276

277

278

279

280

281

282

283

284

285

286

287

288

289

290

291

292

293

294

295

296

297

298

al., 2009; Risebrobakken et al., 2011). Since our data are derived from the subsurface dwelling N. pachyderma (sin) (Kozdon et al., 2009; Simstich et al., 2003; Volkmann, 2000) the observed $\mathrm{SSST}_{\mathrm{Mg} / \mathrm{Ca}}$ decline (Figure $6 \mathrm{C}, \mathrm{D}$ ) probably only partly reflects the declining insolation forcing (Berger and Loutre, 1991) (Figure 6A), but also indicates a gradual reduction in northbound Atlantic Water transport as suggested by Risebrobakken et al. (2011).

\section{Mid Holocene (7.9-2.7 ka BP)}

This period is characterized by the lowest $\mathrm{sSST}_{\mathrm{Mg} / \mathrm{Ca}}$ recorded by $N$. pachyderma $(\mathrm{sin})$. The SiZer analysis identifies no significant changes apart from the overall multi-millennial early Holocene decline ending at $\sim 6 \mathrm{ka} \mathrm{BP}$ and initial increase identified at $\sim 3 \mathrm{ka} \mathrm{BP}$ (Figure $6 \mathrm{C}$, D). This cold interval may be partly driven by continued decrease in insolation (Berger and Loutre, 1991) (Figure 6A) and/or weakened poleward advection of Atlantic Water as indicated by the frequently negative phase of the NAO during the mid-Holocene (Hurrell, 1995; Nesje et al., 2001). Hald et al. (2007) suggest that increased influence of Arctic Water, in response to lowered insolation and reduced oceanic heat advection may have caused the

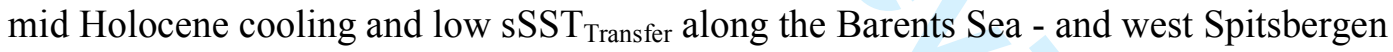
slopes (Ebbesen et al., 2007; Husum and Hald, 2012; Sarnthein et al., 2003) (Figure 6F, G). During the early part of the mid-Holocene, before $\sim 7 \mathrm{ka} \mathrm{BP}$, relatively high phytoplanktonderived biomarker content points to high surface water productivity in the eastern Fram Strait (Müller et al., 2012). This suggests continued influence of the still relatively high insolation on the surface water mass (Müller et al., 2012). However, within the sub-surface water masses the reduced $\mathrm{sSST}_{\mathrm{Mg} / \mathrm{Ca}}$ values suggest an increased influence of Arctic water almost 900 years earlier from $\sim 7.9 \mathrm{ka} \mathrm{BP}$ (Figure 6D). After $\sim 7 \mathrm{ka} \mathrm{BP}$, continued low $\mathrm{sSST}_{\mathrm{Mg} / \mathrm{Ca}}$ recorded by N. pachyderma $(\sin )$ (Figure 6D) are in agreement with weakened poleward advection of Atlantic Water (Hald et al., 2007; Risebrobakken et al., 2011) and cooling of the 
299 surface water mass resulting in lowered productivity and extension of (winter/spring) sea ice

300 (Müller et al., 2012). Faunal distributions in core MSM5/5-712-2 indicate relatively strong

301 Atlantic Water advection until $\sim 5.2$ ka following a slight weakening after $\sim 8 \mathrm{ka}$ BP (Werner

302 et al., 2013). Fluctuating SSST $_{\text {SIMMAX }}$ values during this period, including cooling events at

3036.9 and $6.1 \mathrm{ka} \mathrm{BP}$, are also tied to repeated advances and retreats of the sea-ice margin

304 connected to south east movement of the Arctic Front separating Atlantic and Arctic waters

305 masses (Werner et al., 2013) (Figure 6E).

306 Prevailing cold conditions seen in the $\mathrm{sSST}_{\mathrm{Mg} / \mathrm{Ca}}$ and $\mathrm{SSST}_{\mathrm{SIMMAX}}$ reconstructions and

307 supported by predominantly heavy $\delta^{18} \mathrm{O}$ values measured on $N$. pachyderma $(\sin )$ occur from

3085.2 to $2.7 \mathrm{ka} \mathrm{BP}$ (Werner et al., 2013) (Figure 5A, 6D, E). In combination with increased $\mathrm{IP}_{25}$

309 concentrations (sea ice biomarker) the data indicate more severe sea ice conditions and

310 stronger influence from Arctic water during this period (Müller et al., 2012; Werner et al.,

311 2013) (Figure 6B). The overall similar trend seen in the $\mathrm{sSST}_{\mathrm{Mg} / \mathrm{Ca}}$ and $\mathrm{sSST}_{\mathrm{SIMMAX}}$ suggests

312 that both reconstructions reflect summer conditions (Figure 6D, E). The lower amplitude

313 observed in the $\mathrm{SSST}_{\mathrm{Mg} / \mathrm{Ca}}$ may be related to calcification depth of $N$. pachyderma ( $\left.\sin \right)$ as the

$314 \mathrm{sSST}_{\text {SIMMAX }}$ reconstructs temperatures for $50 \mathrm{~m}$ water depth whereas $\mathrm{sSST}_{\mathrm{Mg} / \mathrm{Ca}}$ probably

315 reflects a somewhat deeper water depth. The modern main habitat depth of N. pachyderma

316 ( $\sin$ ) is 50 to $200 \mathrm{~m}$ water depth in Fram Strait (Volkmann, 2000). At the ice margin and in

317 areas affected by warm Atlantic water masses the main habitat center at $\sim 100 \mathrm{~m}$ water depth

318 (Volkmann, 2000). In ice covered and cold Polar Water masses the average habitat depth lies

319 between 50-100 m (Volkmann, 2000).

320 Late Holocene (2.7-0.3 ka BP)

321 The late Holocene is characterized by significantly increasing $\mathrm{sSST}_{\mathrm{Mg} / \mathrm{Ca}}$ toward the present

322 (Figure 6C, D). The highly fluctuating $\mathrm{sSST}_{\mathrm{Mg} / \mathrm{Ca}}$ signal has values intermittently higher than

323 those recorded during the early Holocene (Figure 6D). During this time, more severe and 
324 gradually increasing ice coverage in the eastern Fram Strait has been inferred from elevated

325 sediment $\mathrm{IP}_{25}$ and IRD contents (Müller et al., 2012) (Figure 6B). In addition, in-phase

326 fluctuations of $\mathrm{IP}_{25}$ and phytoplankton marker contents have been linked to periods of a

327 rapidly advancing and retreating sea ice margin (Müller et al., 2012). The late Holocene

328 expansion of sea ice and general cooling of the surface water masses have also been observed

329 in other sea surface proxy records from the Nordic Seas (e.g. Andersen et al., 2004; Koç et

330 al., 1993; Koç Karpuz and Jansen, 1992) and is in line with the low and declining Northern

331 hemispheric insolation (Berger and Loutre, 1991) (Figure 6A). However, the present

$332 \mathrm{SSST}_{\mathrm{Mg} / \mathrm{Ca}}$ reconstruction and other subsurface proxy records derived from cores situated

333 under the axis of northward Atlantic Water flow in the Nordic Seas register a late Holocene

334 temperature increase that is in contrast to the reduced insolation forcing (Andersson et al.,

335 2009; Dolven et al., 2002; Ebbensen et al., 2007; Risebrobakken et al., 2003; Sarnthein et al.,

336 2003; Werner et al., 2013) (Figure 6E-H). Increased poleward Atlantic Water advection as

337 indicated by the predominantly positive phase of the NAO after $\sim 2 \mathrm{ka} \mathrm{BP}$ (Nesje et al., 2001;

338 Olsen et al., 2012) may partially explain the observed late Holocene subsurface warming

339 (Figure 6D). Furthermore, freshening and cooling of the surface waters due to melting of sea

340 ice and/or icebergs could have resulted in migration of $N$. pachyderma $(\sin )$ to a deeper and

341 possibly warmer part of the water column where conditions were more favorable (Kozdon et

342 al., 2009; Simstich et al., 2003). A gradual migration N. pachyderma ( $\sin$ ) to deeper, less

343 ventilated water masses is inferred by Werner et al. (2013) on the basis of gradually

344 decreasing $\delta^{13} \mathrm{C}$ values after $\sim 3.5 \mathrm{ka} \mathrm{BP}$. Werner et al. (2013) speculate that the light $\delta^{13} \mathrm{C}$

345 values observed in MSM5/5-712-2 and other records in the northern North Atlantic indicate a

346 wider distribution of a sea-ice derived freshwater layer in the Nordic Seas during the late

347 Holocene. We further speculate that northbound Atlantic water masses, as a consequence of a

348 widespread and possibly expanding melt water layer, could have submerged further south 
349 thus becoming gradually more insulated during the late Holocene. This could partially

350 explain the increasingly warmer $\mathrm{SSST}_{\mathrm{Mg} / \mathrm{Ca}}$ observed in the present record (Figure $6 \mathrm{D}$ ) and

351 trend towards less ventilated lighter $\delta^{13} \mathrm{C}$ observed by Werner et al. (2013). Additionally, the

352 low insolation (Berger and Loutre, 1991) (Figure 6A) and the increasingly severe sea ice

353 conditions in the eastern Fram Strait (Müller et al., 2012) (Figure 6B) may have facilitated a

354 shift in the growing season for phytoplankton and foraminifera towards a gradually warmer

355 part of the season (e.g. Farmer et al., 2008). In the Arctic Ocean the highest production and

356 thus main calcification season of N. pachyderma ( $\sin$ ) is observed in August and is likely

357 linked to phytoplankton blooms (Kohfeld et al., 1996; Volkmann, 2000).

358 Conclusions

$359 \mathrm{Mg} / \mathrm{Ca}$ element ratios measured on $N$. pachyderma $(\sin )$ have been used to reconstruct

360 Holocene sub sea surface temperatures $\left(\mathrm{sSST}_{\mathrm{Mg} / \mathrm{Ca}}\right)$ on the West Spitsbergen Slope, eastern

$361 \quad$ Fram Strait.

362 A tentative assessment of foraminiferal calcite preservation based on $\% \mathrm{CaCO}_{3}$ and $\% \mathrm{TOC}$

363 contents in the sediment may suggest preservation problems prior to $\sim 10 \mathrm{ka} \mathrm{BP}$ and possibly

364 also from $\sim 6-3 \mathrm{ka} \mathrm{BP.}$

365 The fluctuating $\mathrm{SSST}_{\mathrm{Mg} / \mathrm{Ca}}$ observed during the earliest part of the early Holocene can

366 probably be associated with variable paleoceanographic conditions in response to lingering

367 sea ice, ice berg and melt water presence. During the early Holocene from $~ 10.5-7.9 \mathrm{ka}$ BP

$368 \mathrm{sSST}_{\mathrm{Mg} / \mathrm{Ca}}$ reach an average value of $\sim 4^{\circ} \mathrm{C}$. These relatively high values probably reflect a

369 strong northward oceanic heat advection in combination with high insolation forcing.

370 A significant long-term (multi-millennial) decrease in $\mathrm{sSST}_{\mathrm{Mg} / \mathrm{Ca}}$ was identified throughout

371 the early Holocene with steeper (sub-millennial) decline recorded at $\sim 9-7 \mathrm{ka} \mathrm{BP}$. The coldest

$372 \mathrm{sSST}_{\mathrm{Mg} / \mathrm{Ca}}$ values observed in the current record, with values averaging $\sim 3^{\circ} \mathrm{C}$, were recorded

373 in two periods from $\sim 7.7-6$ and $\sim 5.2-2.7 \mathrm{ka} \mathrm{BP}$. This cooling during the mid-Holocene may 
374 be attributed to an increased influence of eastward migrating Arctic Water in response to

375 hampered northward oceanic heat advection into the Fram Strait and decreasing insolation

376 forcing.

377 During the late Holocene, after $\sim 2.7 \mathrm{ka} \mathrm{BP}, \mathrm{sSST}_{\mathrm{Mg} / \mathrm{Ca}}$ significantly increased as shown by the

378 SiZer analysis. The $\mathrm{sSST}_{\mathrm{Mg} / \mathrm{Ca}}$ reached an average value of $\sim 5^{\circ} \mathrm{C}$ during the last 1000 year.

379 This $\mathrm{SSST}_{\mathrm{Mg} / \mathrm{Ca}}$ increase can possibly be linked to a stronger advection of Atlantic Water as

380 supported by positive NAO index values combined with an insulating effect of a widespread

381 melt water layer in the northern North Atlantic. The high $\mathrm{sSST}_{\mathrm{Mg} / \mathrm{Ca}}$ values during the late

382 Holocene potentially also could be partly explained by a shift in calcification season and/or

383 change of depth habitat for N. pachyderma (sin).

384 Acknowledgements

385 This work has been carried out within the framework of the International Polar Year project

386 "Arctic Natural Climate and Environmental Changes and Human Adaption: From Science to

387 Public Awareness" (SciencePub) funded by the Research Council of Norway and the Trainee

388 School in Arctic Marine Geology \& Geophysics, University of Tromsø and the Norwegian

389 Research Council. The core was collected onboard the R/V "Maria S. Merian" during the

390 MSM05/5b expedition led by Dr. Gereon Budeus, Alfred Wegener Institute. Patrick Cappa

391 assisted the laboratory work at INSTAAR, University of Colorado. Jan Petter Holm prepared

392 the area map. Two anonymous reviewers, R. Kozdon and K. Zamelczyk gave valuable

393 comments and suggestions. To these institutions and persons we offer our sincere thanks. 


\section{HOLOCENE}

17

400 References

401 Aagaard-Sørensen, S, Husum K, Werner K, et al. (Submitted) A Late glacial-early Holocene

402 multiproxy record, Fram Strait, Polar North Atlantic. Marine Geology

403 Andersen C, Koc N and Moros M (2004) A highly unstable Holocene climate in the subpolar North

$404 \quad$ Atlantic: evidence from diatoms. Quaternary Science Reviews 23: 2155-2166.

405 Andersson C, Pausata FSR, Jansen E et al. (2009) Holocene trends in the foraminifer record from the

406 Norwegian Sea and the North Atlantic Ocean. Climate of the Past Discussions 5: 2081-2113.

407 Archer D, Emerson S, and Reimers C (1989) Dissolution of calcite in deep-sea sediments:pH and $\mathrm{O}_{2}$

408 microelectrode results. Geochimica et Cosmochimica Acta 531: 2831-2845.

409 Barker S, Greaves M, and Elderfield H (2003) A study of cleaning procedures used for foraminiferal

$410 \mathrm{Mg} / \mathrm{Ca}$ paleothermometry. Geochemistry, Geophysics, Geosystems 4: DOI:

$411 \quad 10.1029 / 2003 g c 000559$.

412 Bauch HA, Erlenkeuser H, Spielhagen RF et al. (2001) A multiproxy reconstruction of the evolution

413 of deep and surface waters in the subarctic Nordic seas over the last 30,000 yr. Quaternary

$414 \quad$ Science Reviews 20: 659-678.

415 Berger A and Loutre MF (1991) Insolation values for the climate of the last 10 million years.

416 Quaternary Science Reviews 10: 297-317.

417 Birks CJA and Koç N (2002) A high-resolution diatom record of late-Quaternary sea-surface

418 temperatures and oceanographic conditions from the eastern Norwegian Sea. Boreas 31: $323-$

419344.

420 Björck S, Rundgren M, Ingólfsson Ó and Funder S (1997) The Preboreal oscillation around the

421 Nordic Seas: terrestrial and lacustrine responses. Journal of Quaternary Science 12: 455-465.

422 Bourke RH, Weigel AM and Paquette RG (1988) The Westward Turning Branch of the West

423 Spitsbergen Current. Journal of Geophysical Research 93: 14065-14077.

424 Boyle EA (1983) Manganese carbonate overgrowths on foraminifera tests. Geochimica et

$425 \quad$ Cosmochimica Acta 47: 1815-1819. 


\section{HOLOCENE}

426 Boyle EA and Keigwin LD (1985) Comparison of Atlantic and Pacific paleochemical records for the last 215,000 years: changes in deep ocean circulation and chemical inventories. Earth and Planetary Science Letters 76: 135-150.

Boyle EA and Rosenthal Y (1996) Chemical hydrography of the South Atlantic during the Last Glacial Maximum: $\mathrm{Cd}$ and $\delta^{13} \mathrm{C}$. In: G. Wefer et al. (eds) The South Atlantic: Present and Past Circulation. New York: Springer-Verlag, pp.423-443.

Brown SJ and Elderfield H (1996) Variations in $\mathrm{Mg} / \mathrm{Ca}$ and $\mathrm{Sr} / \mathrm{Ca}$ ratios of planktonic foraminifera caused by postdepositional dissolution: Evidence of shallow Mg-dependent dissolution. Paleoceanography 11(5): 543-551.

435 Chaudhuri P and Marron S (1999) SiZer for exploration of sturctures in curves. Journal of the $436 \quad$ Amerikan Statistical Association 94: 807-823.

437 Dolven JK, Cortese G and Bjørklund KR (2002) A high-resolution radiolarian-derived 438 paleotemperature record for the Late Pleistocene-Holocene in the Norwegian Sea. 439 Paleoceanography 17(4), 1072. DOI:10.1029/2002pa000780.

440 Ebbesen H, Hald M and Eplet TH (2007) Late glacial and early Holocene climatic oscillations on the 441 western Svalbard margin, European Arctic. Quarternary Science Reviews 26: 1999-2011.

442 Elderfield $\mathrm{H}$ and Ganssen GM (2000) Past temperature and $\delta{ }^{18} \mathrm{O}$ of surface ocean waters inferred 443 from foraminiferal $\mathrm{Mg} / \mathrm{Ca}$ ratios. Nature 405: 442-445.

444 Elderfield H, Vautravers M and Cooper M (2002) The relationship between shell size and Mg/Ca, $445 \mathrm{Sr} / \mathrm{Ca}, \delta^{18} \mathrm{O}$, and $\delta^{13} \mathrm{C}$ of species of planktonic foraminifera. Geochemistry, Geophysics, $446 \quad$ Geosystems 3(8), DOI:10.1029/2001gc000194.

447 Emerson S and Bender M (1981) Carbon fluxes at the sediment-water interface of the deep-sea:

448 calcium carbonate preservation. Journal of Marine Research 39: 139-162.

449 Farmer EJ, Chapman MR and Andrews JE (2008) Centennial-scale Holocene North Atlantic surface 450 temperatures from $\mathrm{Mg} / \mathrm{Ca}$ ratios in Globigerina bulloides. Geochemistry, Geophysics, $451 \quad$ Geosystems 9, DOI:10.1029/2008GC002199.

452 Fisher TG, Smith DG and Andrews JT (2002) Preboreal oscillation caused by a glacial Lake Agassiz 453 flood. Quaternary Science Reviews 21: 873-878. 


\section{HOLOCENE}

19

454 Giraudeau J (in prep) EPOC (University Bordeaux 1/CNRS) within the framework of an ongoing 455 IFM-GEOMAR / EPOC collaboration.

456 Hald M and Aspeli R (1997) Rapid climatic shifts of the nothern Norwegian Sea during the last 457 deglaciation and the Holocene. Boreas 26: 15-28.

458 Hald M and Hagen S (1998) Early preboreal cooling in the Nordic Sea region triggered by meltwater.

460

461 Geology 26: 615-618.

Hald M, Ebbesen H, Forwick M et al. (2004) Holocene paleoceanography and glacial history of the West Spitsbergen area, Euro-Arctic margin. Quaternary Science Reviews 23: 2075-2088. 45: 109-208.

Hopkins TS (1991) The GIN Sea--A synthesis of its physical oceanography and literature review 1972-1985. Earth-Science Reviews 30(3-4): 175-318.

Huber R, Meggers H, Baumann KH and Henrich R (2000) Recent and Pleistocene carbonate dissolution in sediments of the Norwegian-Greenland Sea. Marine Geology 165(1-4): 123136.

Hughen KA, Baillie MGL, Bard E et al. (2004) Marine04 marine radiocarbon age calibration, 0-26 cal kyr BP. Radiocarbon 46: 1059-1086.

Hurrell JW (1995) Decadal Trends in the North Atlantic Oscillation Regional Temperatures and Precipitation. Science 269: 676-679.

Husum K and M Hald (2002) Early Holocene cooling events in Malangenfjord and the adjoining shelf, north-east Norwegian Sea. Polar Research 21(2): 267-274.

478 Husum K and M Hald (2012) Arctic planktic foraminiferal assemblages: Implications for subsurface 479 temperature reconstructions. Marine Micropaleontology 96-97(0): 38-47. 
480

481

482

483

484

485

486

487

488

489

490

491

492

493

494

495

496

497

498

499

500

501

502

503

504

505

506

Intergovernmental Panel on Climate Change (2007) Climate Change 2007: The Physical Science Basis. Contribution of Working Group I to the Fourth Assessment Report of the Intergovernmental Panel on Climate Change. Cambridge University Press.

Johnstone HJH, Yu J, Elderfield H and Schulz M (2011) Improving temperature estimates derived from $\mathrm{Mg} / \mathrm{Ca}$ of planktonic foraminifera using X-ray computed tomography-based dissolution index, XDX. Paleoceanography 26(1): PA1215, DOI: 10.1029/2009pa001902.

Knudsen KL, Jiang H, Jansen E et al. (2004) Environmental changes off North Iceland during the deglaciation and the Holocene: foraminifera, diatoms and stable isotopes. Marine Micropaleontology 50: 273-305.

Koç Karpuz N and Jansen E (1992) A high-resolution diatom record of the last deglaciation from the SE Norwegian Sea: Documentation of rapid climatic changes. Paleoceanography 7: 499520.

Koç N, Jansen E and Haflidason H (1993) Paleoceanographic reconstructions of surface ocean conditions in the Greenland, Iceland and Norwegian seas through the last 14 ka based on diatoms. Quaternary Science Reviews 12: 115-140.

Kohfeld KE, Fairbanks RG, Smith SL et al. (1996) Neogloboquadrina pachyderma (sinistral coiling) as paleoceanographic tracers in polar oceans: evidence from Northeast Water Polynya plankton tows, sediments traps, and surface sediments. Paleoceanography 11: 679-699.

Kozdon R, Eisenhauer A, Weinelt M et al. (2009) Reassessing Mg/Ca temperature calibrations of Neogloboquadrina pachyderma (sinistral) using paired $\delta^{44 / 40} \mathrm{Ca}$ and $\mathrm{Mg} / \mathrm{Ca}$ measurements. Geochemistry Geophysics Geosystems 10: Q03005, DOI: 10.1029/2008GC002169

Kristjánsdóttir GB, Lea DW, Jennings AE et al. (2007) New spatial Mg/Ca-temperature calibrations for three Arctic, benthic foraminifera and reconstruction of north Iceland shelf temperature for the past 4000 years. Geochemistry Geophysics Geosystems 8: Q03P21, DOI: $10.1029 / 2006 \mathrm{GC} 001425$

Kucera M, Weinelt M, Kiefer T et al. (2005) Reconstruction of sea-surface temperatures from assemblages of planktonic foraminifera: multi-technique approach based on geographically 


\section{HOLOCENE}

21

507

508

509

510

511

512

513

514

515

516

517

518

519

520

521

522

523

524

525

526

527

528

529

530

531

532

Marnela M, Rudels B, Olsson KA et al. (2008) Transports of Nordic Seas water masses and excess SF6 through Fram Strait to the Arctic Ocean. Progress In Oceanography 78(1): 1-11.

Müller J, Werner K, Stein R et al. (2012) Holocene cooling culminates in sea ice oscillations in Fram Strait. Quaternary Science Reviews 47: 1-14.

Nesje A, Matthews JA, Dahl SO et al. (2001) Holocene glacier fluctuations of Flatebreen and winterprecipitation changes in the Jostedalsbreen region, western Norvay, based on glaciolacustrine sediment records. The Holocene 11: 267-280. DOI:10.1191/095968301669980885

Nürnberg D, Bijma J and Hemleben C (1996) Assessing the reliability of magnesium in foraminiferal calcite as a proxy for water mass temperatures. Geochimica et Cosmochimica Acta 60(5): 803-814.

Olsen J, Anderson NJ and Knudsen MF (2012) Variability of the North Atlantic Oscillation over the past 5,200 years. Nature Geoscience 5: 808-812, DOI:10.1038/ngeo1589 
533 Rasmussen SO, Vinther BM, Clausen HB and Andersen KK (2007) Early Holocene climate

534 oscillations recorded in three Greenland ice cores. Quaternary Science Reviews 26: 1907-

$535 \quad 1914$.

536 Rasmussen TL, Thomsen E, Ślubowska MA et al. (2007) Paleoceanographic evolution of the SW

537 Svalbard margin $\left(76{ }^{0} \mathrm{~N}\right)$ since $20,000{ }^{14} \mathrm{C}$ yr BP. Quaternary Research 67: 100-114.

538 Reimer P, Baillie M, Bard E et al. (2005) IntCal04 Terrestrial Radiocarbon Age Calibration, 0-26 Cal

$539 \quad$ Kyr BP. Radiocarbon 46: 1029-1058.

540 Reimer P, Baillie M, Bard E et al. (2009) IntCal09 and Marine09 Radiocarbon Age Calibration

541 Curves, 0-50,000 Years cal BP. Radiocarbon 51: 1111-1150.

542 Risebrobakken B, Jansen E, Andersson C et al. (2003) A high-resolution study of Holocene

543 paleoclimatic and paleoceanographic changes in the Nordic Seas. Paleoceanography 18:

$544 \quad 1017-1034$.

545 Risebrobakken B, Dokken T, Smedsrud LH et al. (2011) Early Holocene temperature variability in the

546 Nordic Seas: The role of oceanic heat advection versus changes in orbital forcing.

547 Paleoceanography 26(4): PA4206, DOI:10.1029/2011pa002117.

548 Rosenthal Y, Lohmann GP, Lohmann KC and Sherrell RM (2000) Incorporation and preservation of

$549 \mathrm{Mg}$ in Globigerinoides sacculifer: implications for reconstructing the temperature and ${ }^{18} \mathrm{O} /{ }^{16} \mathrm{O}$

$550 \quad$ of seawater. Paleoceanography 15(1): 135-145.

551 Rudels B, Björk G, Nilsson J et al. (2005) The interaction between waters from the Arctic Ocean and

552 the Nordic Seas north of Fram Strait and along the East Greenland Current: results from the

553 Arctic Ocean-02 Oden expedition. Journal of Marine Systems 55(1-2): 1-30.

554 Sarnthein M, Van Kreveld S, Erlenkeuser H et al. (2003) Centennial-to-millennial-scale periodicities

555 of Holocene climate and sediment injections off the western Barents shelf, $75^{\circ} \mathrm{N}$. Boreas 32 :

$556 \quad 447-461$.

557 Schauer U, Fahrbach E, Osterhus S and Rohardt G (2004) Arctic warming through the Fram Strait:

558 Oceanic heat transport from 3 years of measurements. Journal of Geophysical Research 109:

$559 \quad$ C06026, DOI:10.1029/2003JC001823. 
560 Shackleton NJ (1974) Attainment ofisotopic equilibrium between ocean water and the benthonic

561 foraminifera genus Uvigerina: isotopic changes in the ocean during the last glacial. Centre

562 National de la Recherche Scientifique Colleagues Internationeau, 219: 203-209.

563 Simstich J, Sarnthein M and Erlenkeuser H (2003) Paired delta O-18 signals of Neogloboquadrina

564 pachyderma (s) and Turborotalita quinqueloba show thermal stratification structure in Nordic

565 Seas. Marine Micropaleontology 48(1-2): 107-125.

566 Ślubowska M, Koç N, Rasmussen TL and Klitgaard-Kristensen D (2005) Changes in the flow of

567 Atlantic water into the Arctic Ocean since the last deglaciation: Evidence from the northern

568 Svalbard continental margin, $80^{\circ}$ N. Paleoceanography 20: PA001141,

$569 \quad$ DOI: $10.1029 / 2005 P A 001141$

570 Spielhagen RF, Werner K, Sørensen SA et al. (2011) Enhanced Modern Heat Transfer to the Arctic

571 by Warm Atlantic Water. Science 331: 450-453.

572 Stuiver M, Reimer PJ and Reimer RW (2005) CALIB 6.0. [WWW program and documentation].

573 Volkmann R (2000) Planktic foraminifers in the outer Laptev Sea and the Fram Strait - Modern

574 distribution and ecology: Journal of Foraminiferal Research 30: 157-176.

575 Walczowski W, Piechura J, Osinski R and Wieczorek P (2005) The West Spitsbergen Current volume

576 and heat transport from synoptic observations in summer. Deep Sea Research Part I:

577 Oceanographic Research Papers 52: 1374-1391.

578 Walker M, Johnsen S, Rasmussen SO et al. (2009) Formal definition and dating of the GSSP (Global

579 Stratotype Section and Point) for the base of the Holocene using the Greenland NGRIP ice

$580 \quad$ core, and selected auxiliary records. Journal of Quaternary Science 24: 3-17.

581 Werner K, Spielhagen RF, Bauch D, et al. (2013) Atlantic Water advection versus sea-ice advances in

582 the eastern Fram Strait during the last $9 \square \mathrm{ka}$ - multiproxy evidence for a two-phase Holocene.

583 Paleoceanography, 28(2), 283-295.

584 Wilson LJ, Hald M and Godtliebsen F (2011) Foraminiferal faunal evidence of twentieth-century

585 Barents Sea warming. The Holocene 21(4): 527-537. 
24

586 Zamelczyk K, Rasmussen TL, Husum K et al. (2012) Paleoceanographic changes and calcium

587 carbonate dissolution in the central Fram Strait during the last 20 ka yr. Quaternary Research

$588 \quad 78: 405-416$.

589

590

591

592

593

594

595

596

597

598

599

600

601

602

603

604

605

606

607

608

609

610

611

http://mc.manuscriptcentral.com/holocene 


\section{HOLOCENE}

\section{$612 \quad$ Figure captions}

613 Table 1. Radiocarbon dates and calibrations from core MSM5/5-712. The radiocarbon dates

614 were performed by the Leibniz-Laboratory for Radiometric Dating and Isotope Research,

615 Kiel, Germany (KIA) and at Poznań Radiocarbon Laboratory, Poland (Poz). A reservoir age

616 correction of 400 years with an additional reservoir correction $(\Delta \mathrm{R})$ of $151 \pm 51$ was used.

617 Figure 1. (A) Map of the north-eastern North Atlantic Ocean and adjoining seas showing the

618 major currents systems and average position of the Polar and Arctic fronts modified from

619 Marnela et al. (2008). Open circles indicate core location of Kastenlot core MSM05/5-712-2,

620 giant box corer MSM05/5-712-1 and other cores mentioned in the text. Abbreviations: NAC:

621 North Atlantic Current; IRM: Irminger Current; NwASC: Norwegian Atlantic Slope Current;

622 NwAC: Norwegian Atlantic Current; WSC: West Spitsbergen Current; NCaC: North Cape

623 Current; RAW: Re-circulating Atlantic Water; SB: Svalbard Branch; YSC: Yermark Slope

624 Current; ESC: East Spitsbergen Current; EGC: East Greenland Current. (B) Conductivity, 625 temperature, and depth (CTD). Eastern Fram Strait, August 2007.

626 Figure 2. Age model and sedimentation rate (cm/kyr) for Kastenlot core MSM05/5-712-2.

627 Error bars show the $2 \sigma$ standard deviation of the calibrated ages.

628 Figure 3. Correlation and regressions between Holocene $\mathrm{Mg} / \mathrm{Ca}$ and other trace element

629 rations in MSM05/5-712-2. $\mathrm{Mg} / \mathrm{Ca}$ vs. (A) $\mathrm{Al} / \mathrm{Ca}$, (B) $\mathrm{Mn} / \mathrm{Ca}$ and (C) $\mathrm{Fe} / \mathrm{Ca}$ (contamination

630 indicators).

631 Figure 4. $\mathrm{Mg} / \mathrm{Ca}$ concentration and sediment $\mathrm{TOC}$ and $\mathrm{CaCO}_{3}$ contents plotted against

632 calibrated age and depth in core MSM05/5-712-2. (A, B) Sediment TOC and $\mathrm{CaCO}_{3}$ contents 633 (weight \%) in core MSM05/5-712-2 (Grey: (Müller et al., 2012); Black: (Aagaard-Sørensen 634 et al., submitted)). (C) $\mathrm{Mg} / \mathrm{Ca}$ concentration $(\mathrm{mmol} / \mathrm{mol})$. Thin line = raw data. Thick line $=$ 635 5-point running mean. Crosses mark omitted data points. Filled circle shows the average

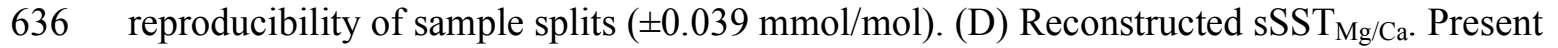


637 day water temperatures at 50 and $200 \mathrm{~m}$ water depth are shown in grey fonts on Y-axis.

638 Diamonds on $\mathrm{X}$-axis indicate radiocarbon dated levels.

639 Figure 5. Reconstruction of $\mathrm{sSST}_{\mathrm{Mg} / \mathrm{Ca}}$ compared to other marine proxies from core MSM5/5-

640 712-2 and MSM5/5-712-1. (A) Ice-volume corrected $N$. pachyderma $(\sin ) \delta^{18} \mathrm{O}$ record (grey

641 line) with 3-point running mean (black line) from core MSM5/5-712-2 (Werner et al., 2013).

642 (B) Reconstructed $\mathrm{sSST}_{\mathrm{Mg} / \mathrm{Ca}}$ (black) (present study) shown with $\mathrm{sSST}_{\mathrm{Mg} / \mathrm{Ca}}$ reconstruction

643 from core MSM5/5-712-1 calculated using exponential temperature equation of Elderfield

644 and Ganssen (2000) (Spielhagen et al., 2011) (purple) and linear temperature equation of

645 Kozdon et al. (2009) (blue). Purple and blue dashed lines indicate calculated core-top

$646 \mathrm{sSST}_{\mathrm{Mg} / \mathrm{Ca}}(\mathrm{C})$ Reconstructed $\mathrm{sSST}_{\mathrm{Mg} / \mathrm{Ca}}$ (black line) and $\mathrm{SSST}_{\mathrm{Mg} / \mathrm{Ca}}$ based on $\mathrm{Mg} / \mathrm{Ca}$ values

647 that have been artificially increased $15 \%$ (grey line). Summer sub sea surface temperatures

648 (at $50 \mathrm{~m}$ water depth) calculated using the SIMMAX modern analogue technique from

649 Spielhagen et al. (2011) (core MSM5/5-712-1) (purple) and Werner et al. (2013) (MSM5/5-

650 712-2) (red) are also shown. Present day water temperatures at 50 and $200 \mathrm{~m}$ water depth are

651 indicated on the y-axis to the right.

652 Figure 6. The reconstructed $\mathrm{sSST}_{\mathrm{Mg} / \mathrm{Ca}}$ for the eastern Fram Strait compared with other proxy 653 records and (sub)SST reconstructions in a south-north transect. (A) June insolation at $80^{\circ} \mathrm{N}$

654 (Berger and Loutre, 1991). (B) Sediment IP $_{25}$ concentrations (Müller et al., 2012). (C) SiZer 655 analysis of reconstructed $\mathrm{SSST}_{\mathrm{Mg} / \mathrm{Ca}}$ from core MSM5/5-712-2. The SiZer map, a function of 656 scale (y-axis: $\left.\log _{10}(\mathrm{~h})\right)$ and location (x-axis: calendar age BP), shows at what given time the 657 proxy record has significant increase (red), decrease (blue), no change (purple) or has 658 insufficient observations for correct inference (grey). (D) Reconstructed $\mathrm{sSST}_{\mathrm{Mg} / \mathrm{Ca}}$. Thin line $659=$ raw data. Thick line $=5$-point running mean. (E) Transfer function summer sSST 660 reconstructions at $50 \mathrm{~m}$ water depth (SIMMAX modern analogue technique) in core 661 MSM5/5-712-2 (Werner et al., 2013). (F) Transfer function summer sSST reconstructions 
$662100 \mathrm{~m}$ water depth (Weighted average partical least squares model) in core MD99-2304

663 (Ebbensen et al., 2007; Husum and Hald, 2012). (G) Transfer function based summer SST

664 reconstructions at $10 \mathrm{~m}$ water depth (Maximum Likelihood model) in Core 23258-2 (Hald et

665 al., 2007; Sarnthein et al., 2003). (H) Transfer function based summer SST reconstructions at

$66610 \mathrm{~m}$ water depth (Maximum Likelihood model) in Cores MD95-2011 and JM97-948/2A

667 (Hald et al., 2007; Risebrobakken et al., 2003).

668 


\section{Table 1}

\begin{tabular}{|c|c|c|c|c|c|c|c|c|}
\hline Core id & Lab. code & Depth range $(\mathrm{cm})$ & Material & ${ }^{14} \mathrm{C}$ age & $\begin{array}{c}\text { Calibrated } \\
\text { age } \pm 2 \sigma\end{array}$ & $\begin{array}{c}2 \sigma \text { max cal. age } \\
\text { (cal. age intercepts) } \\
2 \sigma \text { min cal. age }\end{array}$ & $\begin{array}{l}\text { Reservoir age } \\
(\mathrm{R}=400+\Delta \mathrm{R})\end{array}$ & References \\
\hline MSM5/5-712-2 & KIA 45217 & $10-12$ & N. pachyderma & $815 \pm 25$ & $317 \pm 131$ & $186(317) 447$ & $551 \pm 51$ & Werner et al., 2013 \\
\hline MSM5/5-712-2 & KIA 41024 & $20-22$ & N. pachyderma & $1570 \pm 25$ & $972 \pm 141$ & $831(972) 1113$ & $551 \pm 51$ & Werner et al., 2013 \\
\hline MSM5/5-712-2 & KIA 45218 & $27-29$ & N. pachyderma & $1985 \pm 25$ & $1393 \pm 118$ & $1275(1393) 1510$ & $551 \pm 51$ & Werner et al., 2013 \\
\hline MSM5/5-712-2 & KIA 45219 & $40-42$ & N. pachyderma & $2565 \pm 25$ & $2056 \pm 165$ & 1891(2056)2220 & $551 \pm 51$ & Werner et al., 2013 \\
\hline MSM5/5-712-2 & SacA 19113 & $60-61$ & N. pachyderma & $3365 \pm 30$ & $3029 \pm 175$ & $2854(3029) 3203$ & $551 \pm 51$ & $\begin{array}{l}\text { Giraudeau } \\
\text { (in prep) }\end{array}$ \\
\hline MSM5/5-712-2 & SacA 19114 & $94-95$ & N. pachyderma & $4915 \pm 30$ & $5041 \pm 189$ & $4852(5041) 5230$ & $551 \pm 51$ & $\begin{array}{l}\text { Giraudeau } \\
\text { (in prep) }\end{array}$ \\
\hline MSM5/5-712-2 & SacA 19115 & $138.5-139.5$ & N. pachyderma & $6440 \pm 30$ & $6756 \pm 151$ & $6605(6756) 6906$ & $551 \pm 51$ & $\begin{array}{l}\text { Giraudeau } \\
\text { (in prep) }\end{array}$ \\
\hline MSM5/5-712-2 & KIA 38080 & $168.5-169.5$ & N. pachyderma & $7305 \pm 35$ & $7630 \pm 126$ & 7504(7630) 7756 & $551 \pm 51$ & Werner et al., 2013 \\
\hline MSM5/5-712-2 & KIA 41025 & $191.5-192.5$ & N. pachyderma & $7815 \pm 45$ & $8133 \pm 157$ & $7976(8133) 8290$ & $551 \pm 51$ & Werner et al., 2013 \\
\hline MSM5/5-712-2 & Poz-30723 & $214-215$ & N. pachyderma & $8362 \pm 45$ & $8749 \pm 209$ & 8540 (8749) 8958 & $551 \pm 51$ & $\begin{array}{c}\text { Present } \\
\text { study }\end{array}$ \\
\hline MSM5/5-712-2 & KIA 37423 & $280-281$ & N. pachyderma & $9220 \pm 50$ & $9797 \pm 252$ & 9551 (9797) 10042 & $551 \pm 51$ & $\begin{array}{l}\text { Present } \\
\text { study }\end{array}$ \\
\hline MSM5/5-712-2 & Poz-30725 & $322-323$ & N. pachyderma & $9580 \pm 47$ & $10310 \pm 158$ & $10152(10310) 10468$ & $551 \pm 51$ & $\begin{array}{l}\text { Present } \\
\text { study }\end{array}$ \\
\hline MSM5/5-712-2 & Poz-30726 & $428-431$ & N. pachyderma & $12358 \pm 63$ & $13629 \pm 197$ & $13432(13629) 13826$ & $551 \pm 51$ & $\begin{array}{c}\text { Present } \\
\text { study }\end{array}$ \\
\hline
\end{tabular}




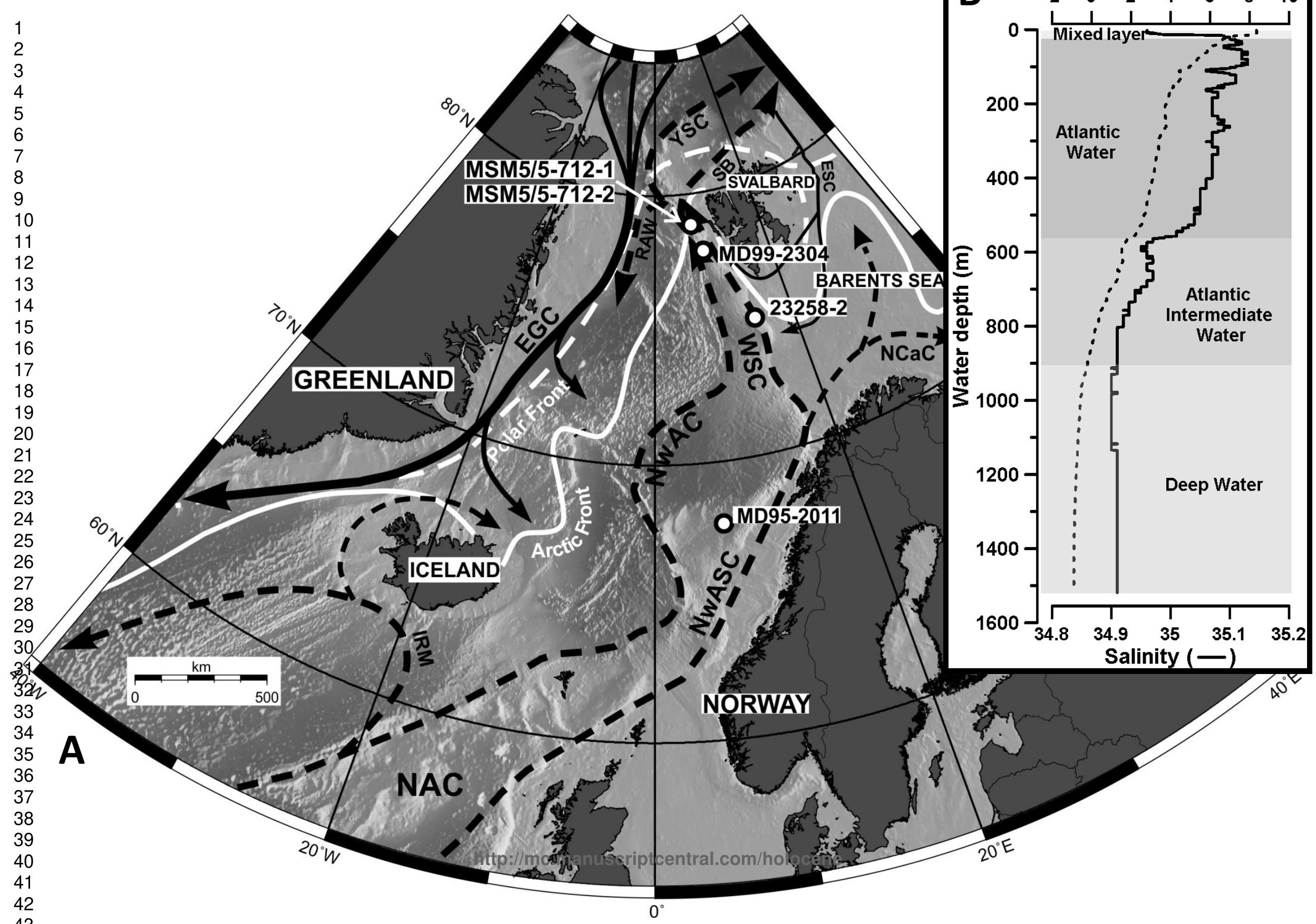




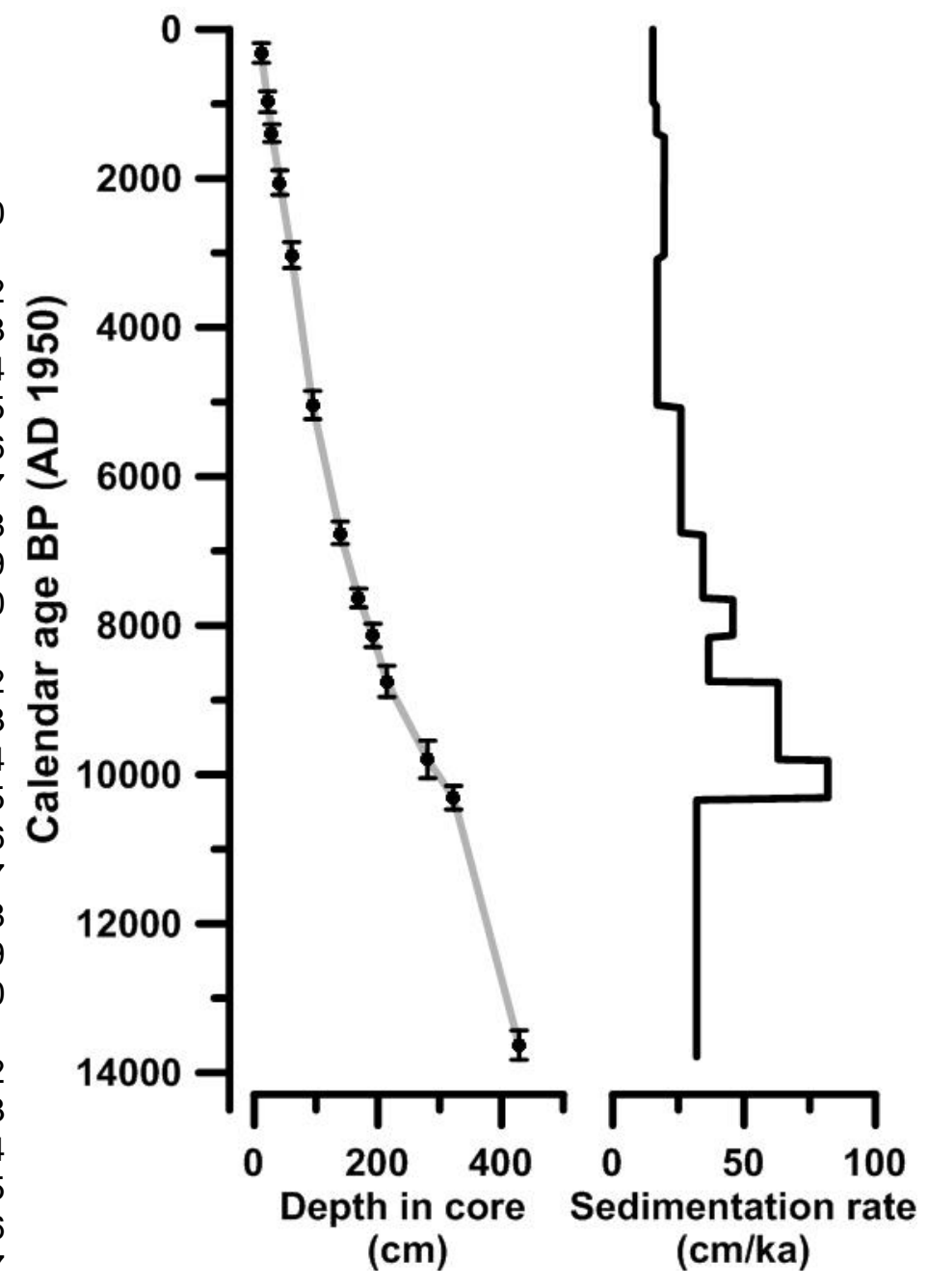

http://mc.manuscriptcentral.com/holocene 

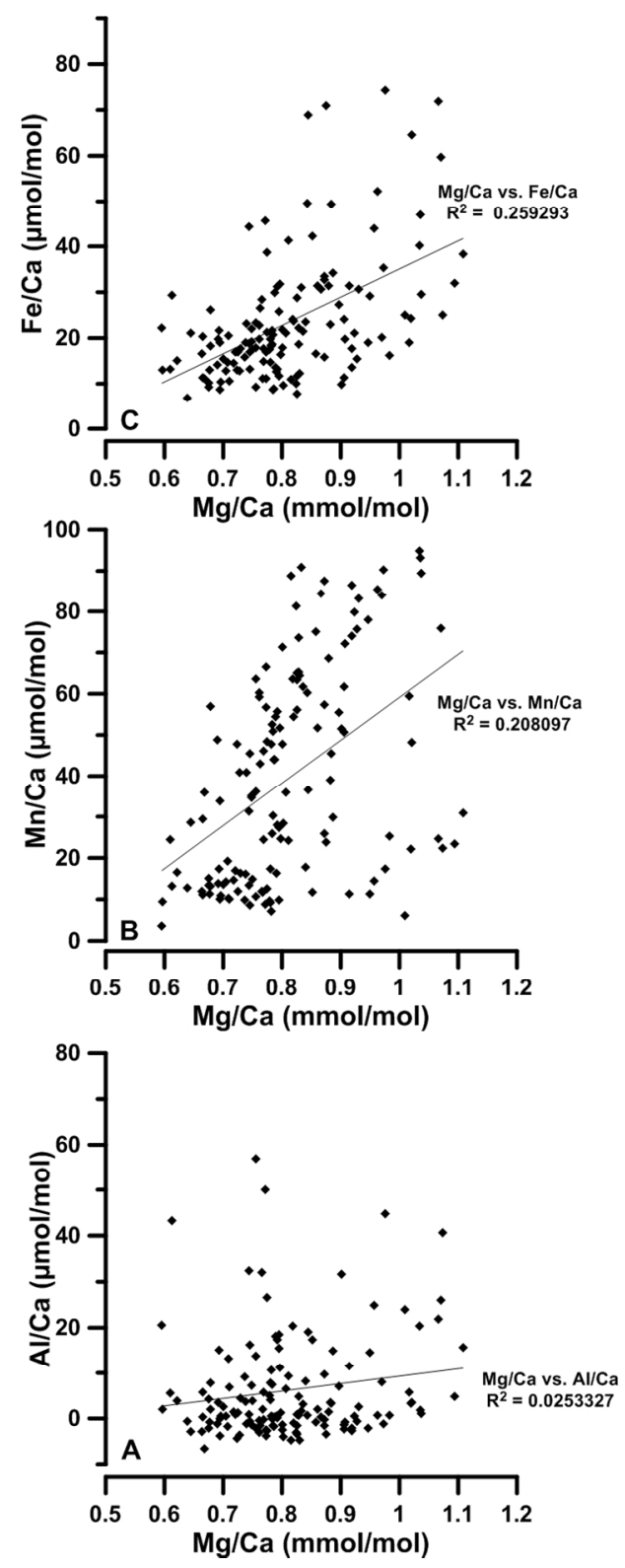

$280 \times 476 \mathrm{~mm}(96 \times 96$ DPI $)$ 


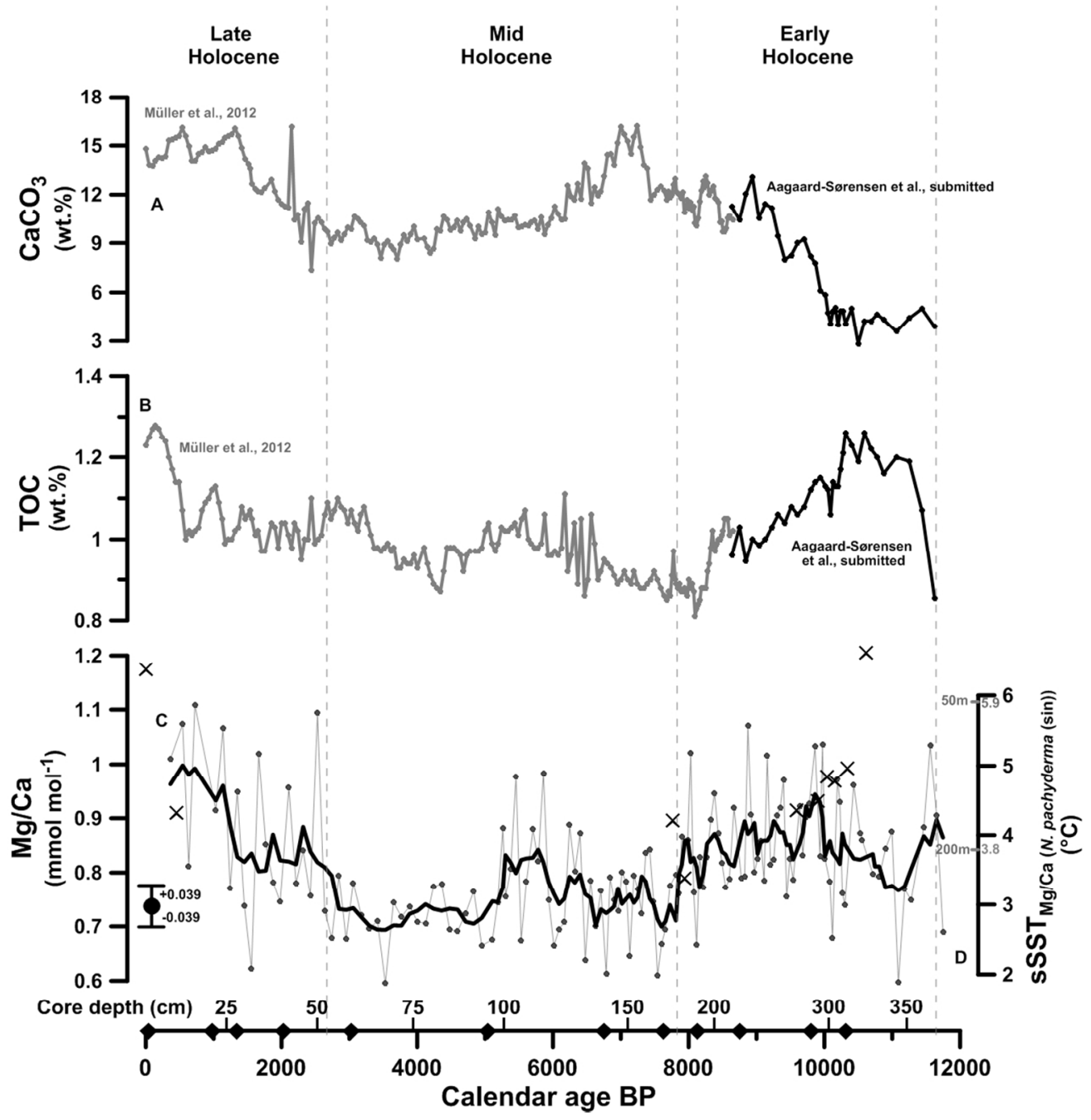

$337 \times 350 \mathrm{~mm}(96 \times 96$ DPI $)$ 

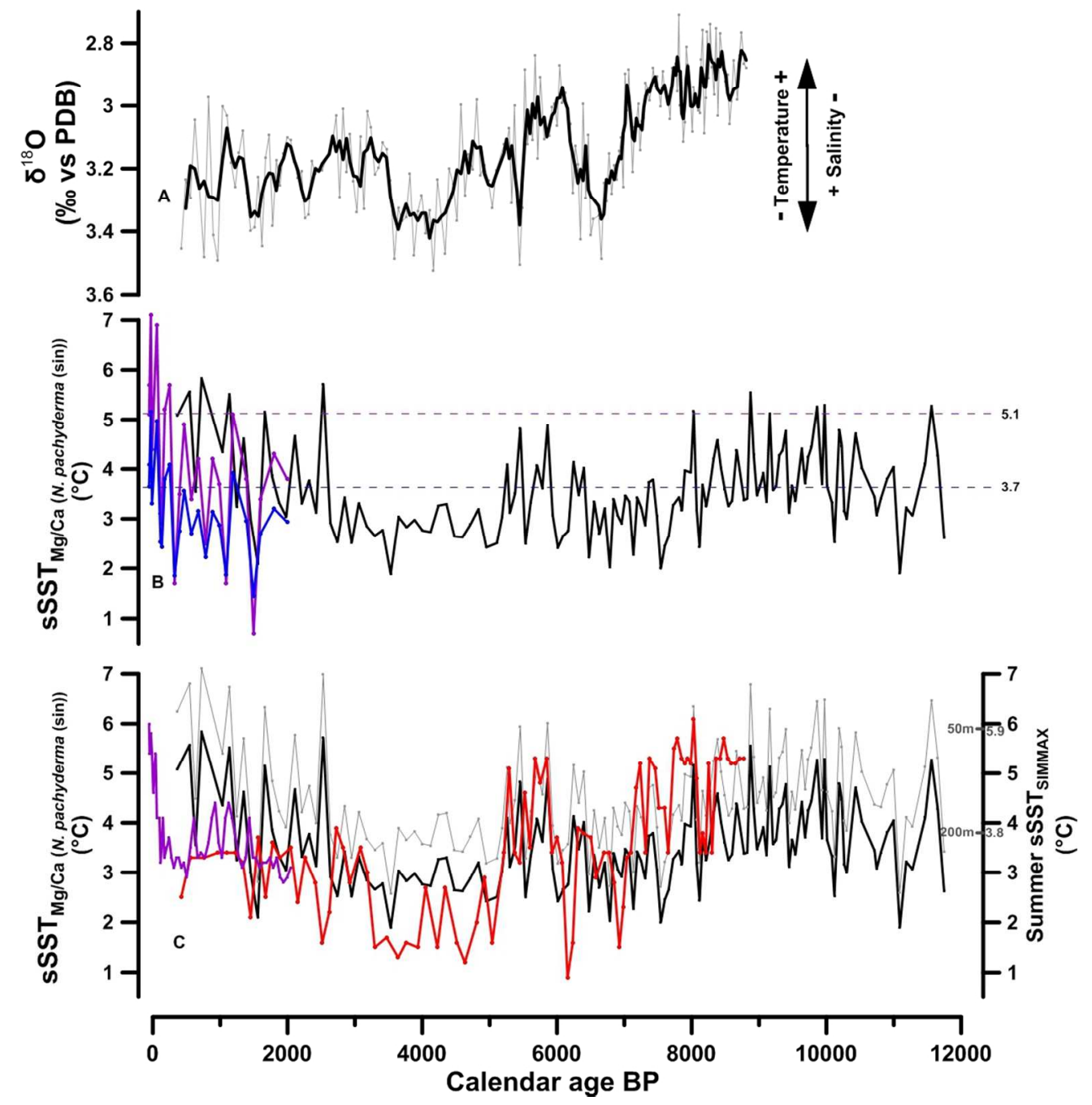

$332 \times 352 \mathrm{~mm}(96 \times 96 \mathrm{DPI})$ 

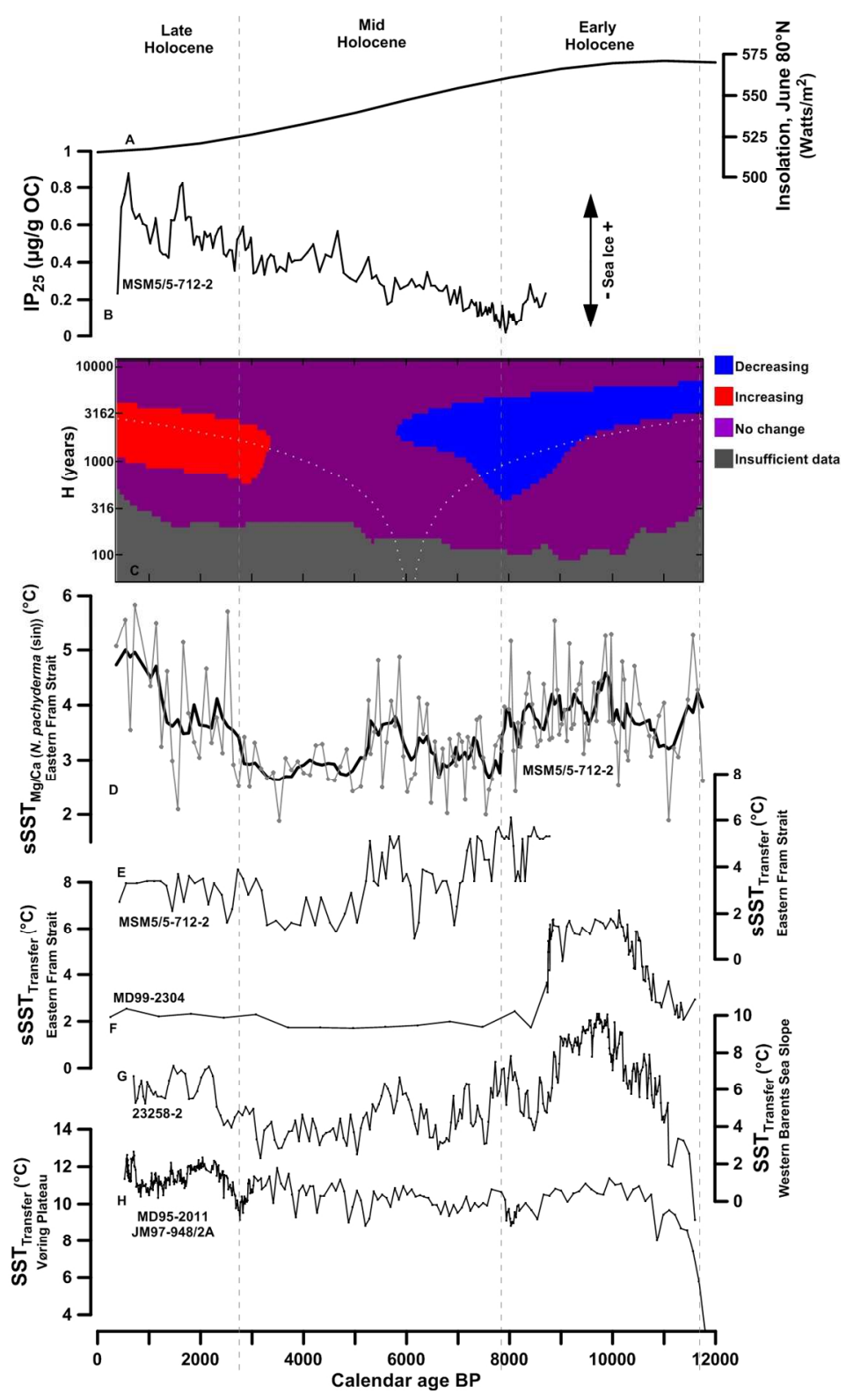

$342 \times 564 \mathrm{~mm}(96 \times 96 \mathrm{DPI})$ 